\title{
The Adaptation of Silica Capture RT-PCR for the Detection of Potato Virus $Y$
}

\author{
Bogumila Zacharzewska • Agnieszka Przewodowska • \\ Krzysztof Treder
}

Published online: 8 March 2014

(C) The Author(s) 2014. This article is published with open access at Springerlink.com

\begin{abstract}
In Poland, it is mandatory to index seed tubers for Potato virus $Y$ (PVY), Potato virus $M$ (PVM) and Potato leafroll virus (PLRV). Currently, the incidence of viral infection in seed tubers is determined by grow-out test. Direct testing of tubers after harvest by reverse transcription polymerase chain reaction (RT-PCR) can be beneficial but its application is so far hampered by the high cost of commercial kits for RNA isolation and poor usability of manual methods for routine diagnostics. In this work, we compare several commercial kits with the silica capture RT-PCR (SC-RTPCR) for direct detection of PVY. The silica capture of RNA in conjunction with optimized PCR conditions facilitates quick and sensitive detection of PVY and offers cost effective and reliable alternative to commercial kits.
\end{abstract}

Resumen En Polonia, los tubérculos-semilla son analizados obligatoriamente para el virus Y de la papa (PVY), virus M de la papa (PVM) y el enrollamiento de la hoja (PLRV). Actualmente, la incidencia de infección viral en tubérculosemilla se determina por pruebas durante el crecimiento. Las pruebas directas de tubérculos después de la cosecha con la reverso-transcripción por la reacción en cadena de la polimerasa (RT-PCR) pudiera ser benéfica, pero su aplicación se limita por el alto costo de juegos comerciales para el aislamiento de ARN y por el pobre uso de métodos manuales para diagnósticos de rutina. En este trabajo comparamos

\footnotetext{
B. Zacharzewska $\cdot$ A. Przewodowska $\cdot K$. Treder $(\bowtie)$

Laboratory of Molecular Diagnostic and Biochemistry, Department of Potato Protection and Seed Science in Bonin, Plant Breeding and Acclimatization Institute - National Research Institute, 76-009 Bonin, Poland

e-mail: k.treder@ihar.edu.pl

B. Zacharzewska

e-mail: b.zacharzewska@ihar.edu.pl

A. Przewodowska

e-mail: a.przewodowska@ihar.edu.pl
}

varios juegos comerciales con la efectividad de costos de captura de sílice RT-PCR para detección directa de PVY. La sensibilidad en la detección del PVY en ARN preparado por captura de sílice fue igual o mayor que en ARN aislado usando juegos comerciales. El ARN por captura de sílice junto con condiciones óptimas de PCR facilita la detección rápida y sensible de PVY y ofrece una alternativa efectiva, en costos y confiabilidad, a los juegos comerciales.

Keywords Potato virus Y · Silica capture $\cdot$ RNA extraction . RT-PCR

\section{Introduction}

Viral diseases are a major cause of degeneration of the potatoes and disqualification of seed tubers (Singh 1999; Whitworth et al. 2006) and their control is strictly based on the production of healthy seed material (Wróbel and Wasik 2013). For the last three decades health certification of seed tubers is performed by grow-out test. This involves the removal of the eye plugs from tubers, chemical breaking of the dormancy, sprouting in the dark and planting in the greenhouse. In the final stage, leaves of 4-6 weeks old offspring potatoes are tested by the double sandwich enzyme-linked immunosorbent assay (DAS-ELISA) (Clark and Adams 1977). This method is expensive and time consuming, thus, direct tuber testing is strongly needed (Treder et al. 2009; Wróbel 2014). Unfortunately, the concentration of viral particles in potato tubers is too low for ELISA test (Hill and Jackson 1984). Reverse transcription PCR is much more sensitive and since 1990s has been adopted for detection of potato viruses directly in tuber extracts (Spiegel and Martin 1993; Singh and Singh 1996; Singh 1998; Singh et al. 2002; Crosslin and Hamlin 2011). Many variations of RT-PCR have been developed focusing on (i) identification and elimination 
of factors negatively affecting virus detection in tubers (Singh and Singh 1996), (ii) development of standardized protocols (Singh 1998; Crosslin and Hamlin 2011), (iii) simplification of sample preparation (Nolasco et al. 1993; Singh et al. 2004), (iv) multiplexing (Nie and Singh 2000; Singh and Nie 2003; Du et al. 2006; Li et al. 2008;) and (v) real time detection (Knorr et al. 1996; Boonham et al. 2000; Agindotan et al. 2007; Mortimer-Jones et al. 2009; Singh et al. 2012). However, reports comparing performance of RT-PCR (Barker et al. 1993; Bolotova et al. 2009), and real-time RT-PCR (Fox et al. 2005) with grow-out test have shown that the reliability of the latter method is either equal or more. Sample processing and cost of RNA extraction may impose main problem for successful adaptation of RT-PCR to routine tuber indexing (Boonham et al. 2008). Therefore, in this paper, we describe an attempt to adjust manual method for easy isolation of RNA from potato tissue. We chose for this purpose the isolation on the silica gel, first described by Boom et al. (1990) and adapted for detection of plant viruses as Silica Capture RTPCR (Malinowski 1997). As a model virus to study we selected potato virus Y (PVY) due to current threat of this virus to potato crop (Kostiw 2011; Wróbel and Wassik 2013).

\section{Materials and Methods}

\section{Production of PVY-Infected Plants}

Certified, virus-free tubers of cultivar Sagitta were planted in experimental fields during spring. Offspring tubers were collected in September. Eye plugs were removed, soaked for $15 \mathrm{~min}$. in mixture of gibberelic acid and kinetin $(1 \mathrm{mg} / 1 \mathrm{~L}$ both), washed with water and planted. Resulting plants were tested for PVY by DAS-ELISA (PVY polyclonal Complete kit, Bioreba). PVY-infected plants were selected for further work. Thus, the source of the virus was natural field infection.

\section{RNA Isolation Using Commercial Kits}

Leaves of PVY-positive plants were collected, cut into small squares and mixed. From this sample $100 \mathrm{mg}$ aliquots were weighted and used as source for RNA isolation using commercial kits according to respective protocols. All isolations were performed in duplicates. A range of relative economical RNA extraction kits in Poland were compared. The kits include: A) NucleoSpin ${ }^{\circledR}$ RNA Plant (Cat. No. 740949.10, Macherey-Nagel), B) GeneJet RNA Purification (Cat.No.K0731, Thermo Scientific), C) RNA 3-zone (Cat.No.RA1000-10, Novazym), D) Plant RNA MiniKit (Cat.No.SY341011, Syngen), E) Total RNA purification from bacteria culture, cell culture, tissue or blood (Cat.No.031-25, A\&A Biotechnology) and F) Isolate Plant RNA (Cat. No.BIO-52071, Bioline). Kit $\mathrm{C}$ is similar to Trizol from
Invitrogen, thus requires protein removal, RNA precipitation and several wash steps while the other kits are based on the mini-spin columns with silica membranes. Among chosen kits the least expensive was kit $\mathrm{C}$ and the most expensive (7-fold higher cost per sample) — kit A (Table 1). RNAs were extracted from leaves of PVY-infected cultivar Sagitta following procedures recommended by respective vendors. In general, kits based on mini-spin columns were very convenient and allow quick RNA purification. All required initial homogenization of tissue in liquid nitrogen. Typical final RNA elution volumes were $50 \mu \mathrm{l}$.

\section{Total Nucleic Acids Isolation on Silica Gel}

Silica suspension, buffers L6 and L2 were prepared as described by Boom et al. (1990). Isolation was performed according to Malinowski (1997). Samples $(0.1 \mathrm{ml})$ were added to tubes containing $0.05 \mathrm{ml}$ of a suspension of the silica in $0.9 \mathrm{ml}$ of buffer L6. Tubes were gently vortexed, incubated for $10 \mathrm{~min}$ at room temperature, shaken again and centrifuged for $15 \mathrm{~min}$ at $12,000 \mathrm{~g}$. The supernatant was discarded and the pellet was washed twice with $1 \mathrm{ml}$ of buffer L2, twice with $1 \mathrm{ml}$ of $70 \%$ ethanol and once with $1 \mathrm{ml}$ of acetone. The washing steps consisted of centrifugation for $2 \mathrm{~min}$ at $12,000 \mathrm{~g}$ and supernatant removal. The pellet was dried for $10 \mathrm{~min}$ at $56^{\circ} \mathrm{C}$ in the thermoblock. The silica was resuspended in $0.05 \mathrm{ml}$ of sterile water, gently vortexed and incubated for $10 \mathrm{~min}$ at $56^{\circ} \mathrm{C}$. Silica was pelleted by centrifugation for $2 \mathrm{~min}$. at $12,000 \mathrm{~g}$, and the supernatant was collected. Final preparation, containing both total RNA and DNA was used for virus detection without DNA removal.

\section{Determination of RNA Quality and Quantity}

RNA concentration and purity were determined using an EP$\mathrm{OCH}$ (BioTek) microplate spectrophotometer by measuring the absorbance at $260 \mathrm{~nm}$ and $280 \mathrm{~nm}$. The ratio A260/A280 was used to assess the purity of the isolated RNAs.

One $\mu \mathrm{g}$ of RNA from each sample was digested with DNAse I according to manufactures (Novazym). RNA preparations were separated on a $1.5 \%$ agarose gel at $140 \mathrm{~V}$ for $40 \mathrm{~min}$ and stained with GelGreen dye (Biotium). Gels were excited using blue box (Invitrogen) and documented with Nikon D90 with an orange filter.

\section{Reverse Transcription and PCR}

Reverse transcription reactions were carried out with the Reverse Super Verte KIT with random primers (Novazym) following the manufactures protocol. $1 \mu \mathrm{l}$ of template RNA or nucleic acid extract was mixed with $1 \mu \mathrm{l}$ of random primers $(0.2 \mu \mathrm{g})$ and $9 \mu \mathrm{l}$ of RNase-free water. Samples were incubated at $70{ }^{\circ} \mathrm{C}$ for $5 \mathrm{~min}$ and chilled on ice for $3 \mathrm{~min}$. Next $9 \mu \mathrm{l}$ of 
Table 1 Comparison of cost efficiency and performance of investigated methods of RNA extraction

\begin{tabular}{|c|c|c|c|c|c|c|c|}
\hline Kit & A & $\mathrm{B}$ & $\mathrm{C}$ & $\mathrm{D}$ & E & $\mathrm{F}$ & G \\
\hline Cost/izolation (Euro) & 4.2 & 2.8 & 0.6 & 1.6 & 2.0 & 3.7 & 1.1 \\
\hline Purification time (min) & 30 & 60 & $150-180$ & 30 & 45 & 50 & 50 \\
\hline Concentration $[\mathrm{mg} / \mathrm{ml}]$ & 0.31 & 0.52 & 0.67 & 0.30 & 0.49 & 0.26 & 0.61 \\
\hline Yield $[\mu \mathrm{g}]$ & 15 & 26 & 34 & 15 & 24 & 13 & 30 \\
\hline Purity (ratio 260/280) & 2.17 & 2.09 & 2.00 & 2.13 & 2.17 & 2.13 & 1.87 \\
\hline
\end{tabular}

A - NucleoSpin RNA Plant, B - GeneJet RNA Purification, C - RNA 3-Zone, D - Plant RNA MiniKit, E - A\&A, F - Isolate Plant RNA, G - silica

the RT mixture was added. Final RT reaction $(20 \mu \mathrm{l})$ contained: $1 \mathrm{mM}$ dNTPs, 1xM-MLV buffer, $5 \mathrm{U}$ of Ribonuclease A Inhibitor (Novazym) and 200U of Moloney murine leukemia virus (M-MLV) reverse transcriptase (Novazym). Samples were incubated at $25{ }^{\circ} \mathrm{C}$ for $10 \mathrm{~min}, 60{ }^{\circ} \mathrm{C}$ for $60 \mathrm{~min}$ and $70{ }^{\circ} \mathrm{C}$ for $10 \mathrm{~min}$.

DNA was amplified by PCR using primers: forward: Y5F (5'-GGACCGDCAAATCCAGATGG-3'), nt 3804-3823 and reverse: Y5R (5'-GAYTTYCCMGACCCAACAGC-3'), nt 3962-3943 (nt positions corresponds to PVY isolate with accession number: FJ214726) generating a 159 bp product. To design this primer set, full genomes of $219 \mathrm{PVY}$ isolates were downloaded from GenBank and aligned using Geneious 5.0.4 (Biomatters). Primer pair Y5 was designed using the same software to amplify conserved region inside 5 '-terminal end of cytoplasmic inclusion protein coding sequence.

PCR was performed using a $25 \mu \mathrm{l}$ reaction mixture: $2.5 \mu \mathrm{l}$ of cDNA, $2.5 \mathrm{mM} \mathrm{MgCl} 2,0.2 \mathrm{mM}$ dNTPs, $0.8 \mu \mathrm{M}$ of each forward and reverse primer and 1.25 U Go-Taq HotStart Polymerase (Promega). The temperature profile followed: initial denaturation at $95^{\circ} \mathrm{C}$ for $2 \mathrm{~min}, 35$ cycles at $92^{\circ} \mathrm{C}$ for $30 \mathrm{~s}$, annealing at $58^{\circ} \mathrm{C}$ for $40 \mathrm{~s}$, extension at $72{ }^{\circ} \mathrm{C}$ for $1 \mathrm{~min}$ and final extension at $72{ }^{\circ} \mathrm{C}$ for $5 \mathrm{~min}$. The reaction products were separated on $1.5 \%$ agarose at $140 \mathrm{~V}$ for $50 \mathrm{~min}$ and stained with GelGreen dye (Biotium). Gels were excited using blue box (Invitrogen) and documented with Nikon D90 with an orange filter.

\section{Results}

Comparison of Yield and Quality of RNA Isolated by Different Methods

Kits A, B, C, D, E and F yielded respectively 15, 26, 34, 15, $24,13 \mu \mathrm{g}$ of total RNA (Table 1). Silica capture yielded $30 \mu \mathrm{g}$ of total nucleic acids. The 260/280 ratio of purified RNAs was equal or higher to 2.0 for all tested kits except silica capture were it was equal to 1.9 (Table 1). The RNA integrity analysis by agarose gel electrophoresis before (Fig. 1a) and after treatment with Deoxyribonuclease I (Fig. 1b). showed that all preparations contained good quality, not fragmented total
RNA, however in most preparations some DNA contaminations were present (compare Fig. 1a vs b).

To examine whether the quality of extracted RNAs was sufficient for testing PVY presence by RT-PCR, equal volumes of preparations were reverse transcribed and the resulting cDNAs were amplified by PCR using PVY specific primers set $\mathrm{Y} 5$. As expected a specific PCR product (159 bp) was observed on the gel (Fig. 2) for all investigated RNA isolation procedures.

Comparison of Sensitivity of Detection of PVYin RNAs Prepared by Different Procedures

To check if the choice of RNA isolation procedure can affect sensitivity of PVY detection by RT-PCR all RNAs were adjusted to $100 \mathrm{ng} / \mathrm{ml}$ and 10 -fold dilutions were prepared up to $1 \mathrm{pg} / \mathrm{ml}$. For simplification total nucleic acids prepared by silica capture were diluted the same way, thus in fact total RNA load in the dilutions was lower for this method in comparison with others. All dilutions were reverse transcribed and resulting cDNAs were tested by PCR and analyzed by agarose gel electrophoresis. At higher RNA concentrations strong PVY-specific band was visible for all RNA isolation methods. However at lowest RNA concentration $(1 \mathrm{pg} / \mathrm{ml}$ of total RNA) a faint but clear PVY-specific band was detected only in RNA samples isolated using the silica capture, kit B and kit D (Fig. 3).

\section{Discussion}

Here, we show that combination of silica capture of total nucleic acids with optimized RT-PCR conditions facilitates sensitive PVY detection. This method was developed for routine purification of nucleic acids from clinical specimens (Boom et al. 1990) and was adapted for diagnosis of plant viruses by Malinowski (1997). However, to our knowledge, this is the first report of its application to the detection of viral pathogen in extracts from potato tissue. The method combines potent denaturing properties of guanidine thiocyanate which inhibits ribonucleases (Chomczynski and Sacchi 1987) along with the property of silica to selectively binds to nucleic acids 
Fig. 1 Influence of method of RNA isolation on the RNA quality. Electrophoresis of total RNA on a $1.5 \%$ agarose gel. RNA preparations were electrophoresed directly after isolation (a) and after DNase I treatment (b). Lane 1, MachereyNagel; Lane 2, Thermo Scientific; Lane 3, Novazym; Lane 4,

Syngen; Lane 5, A\&A

Biotechnology; Lane 6, Bioline; Lane 7, Silica capture. Duplicated lanes corresponds to two independent isolations performed by the same method
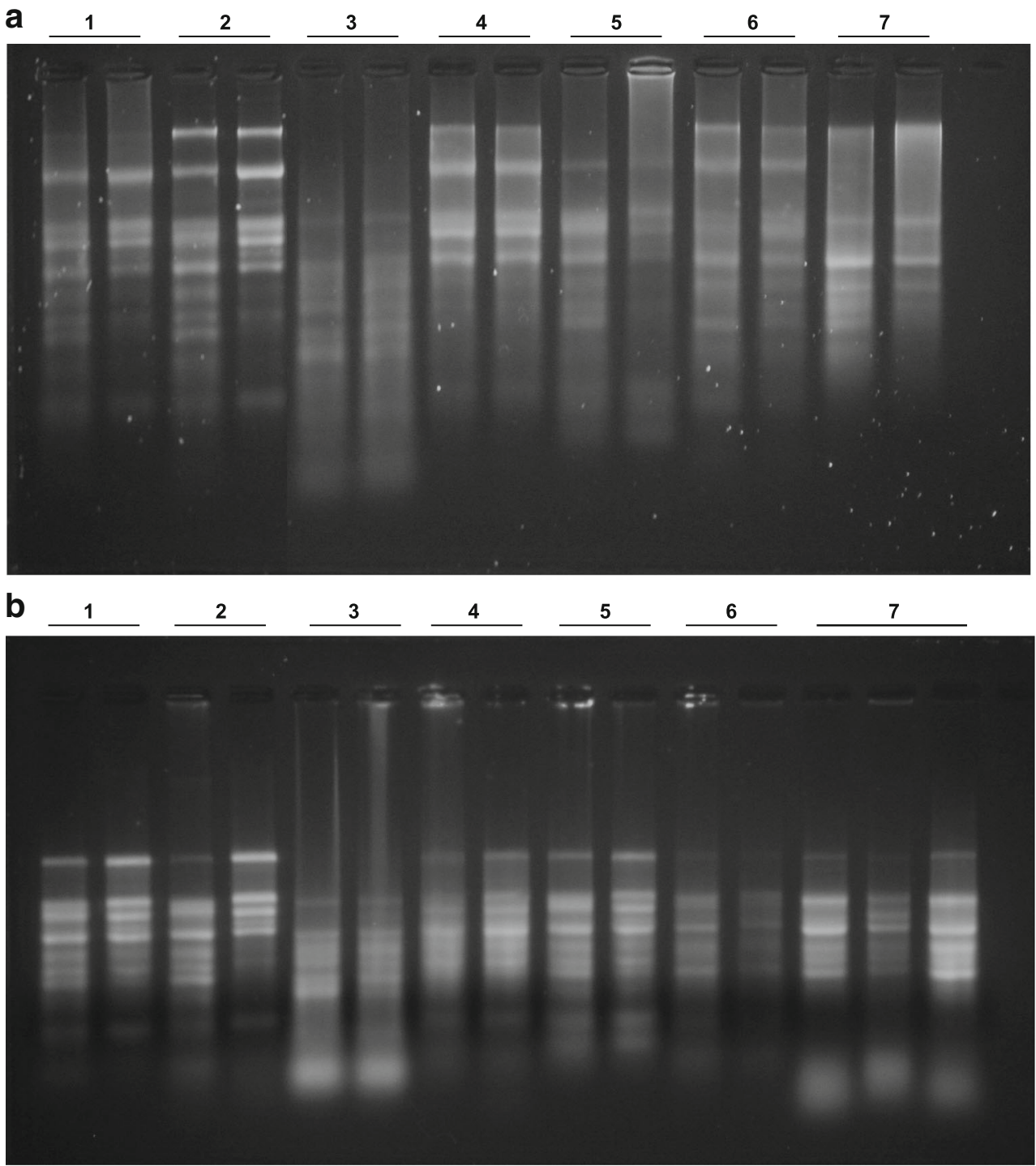

in the presence of chaotropic salts (Marko et al. 1982). Therefore, we compared this method with a range of relative economical RNA extraction kits in Poland. In general all tested methods allowed for isolation of good quality total RNA. Among tested kits the most convenient were kit A and kit D. Procedure in both cases was accomplished just in $30 \mathrm{~min}$ but

Fig. 2 Confirmation of presence of PVY in RNAs isolated by different methods by the RT-PCR reaction. Isolated RNA samples were reverse transcribed and amplified by PCR with KT-Y5 primers. Lane 1, Macherey-Nagel; Lane 2, Thermo Scientific; Lane 3, Novazym; Lane 4, Syngen; Lane 5, A\&A Biotechnology; Lane 6, Bioline; Lane 7, Silica capture; Lane 8, positive control with RNA from purified PVY; Lane 9, negative control with RNA from virus-free plant; Lane $\mathrm{M}, 1 \mathrm{~Kb}$ DNA Ladder

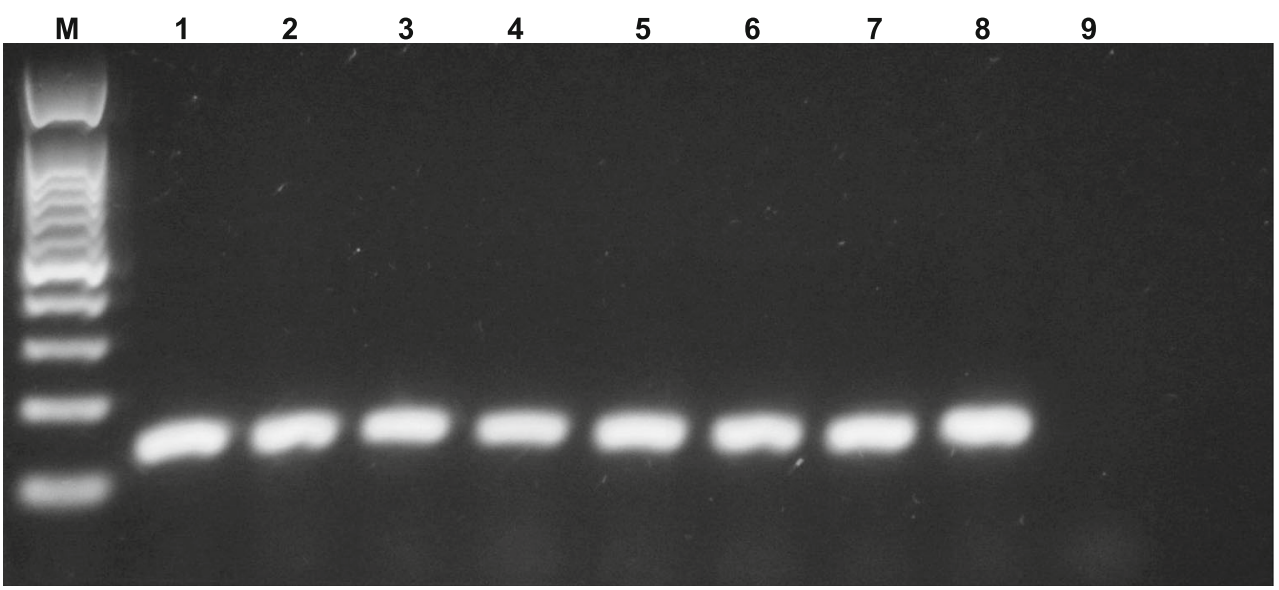


Fig. 3 Determination of the sensitivity of PVY detection by the RT-PCR in RNA samples prepared by different isolation methods. Influence of RNA isolation methods on PVY detection was estimated in RNA dilutions by RT-PCR with Y5 starter pair. Lane 1-6, 10-fold serial dilutions from $100 \mathrm{ng}$ to $1 \mathrm{pg}$ amount of RNA added to RT; Lane 7, mock; Lane 8, negative control with RNA from virus free plant; Lane M, 1Kb DNA Ladder
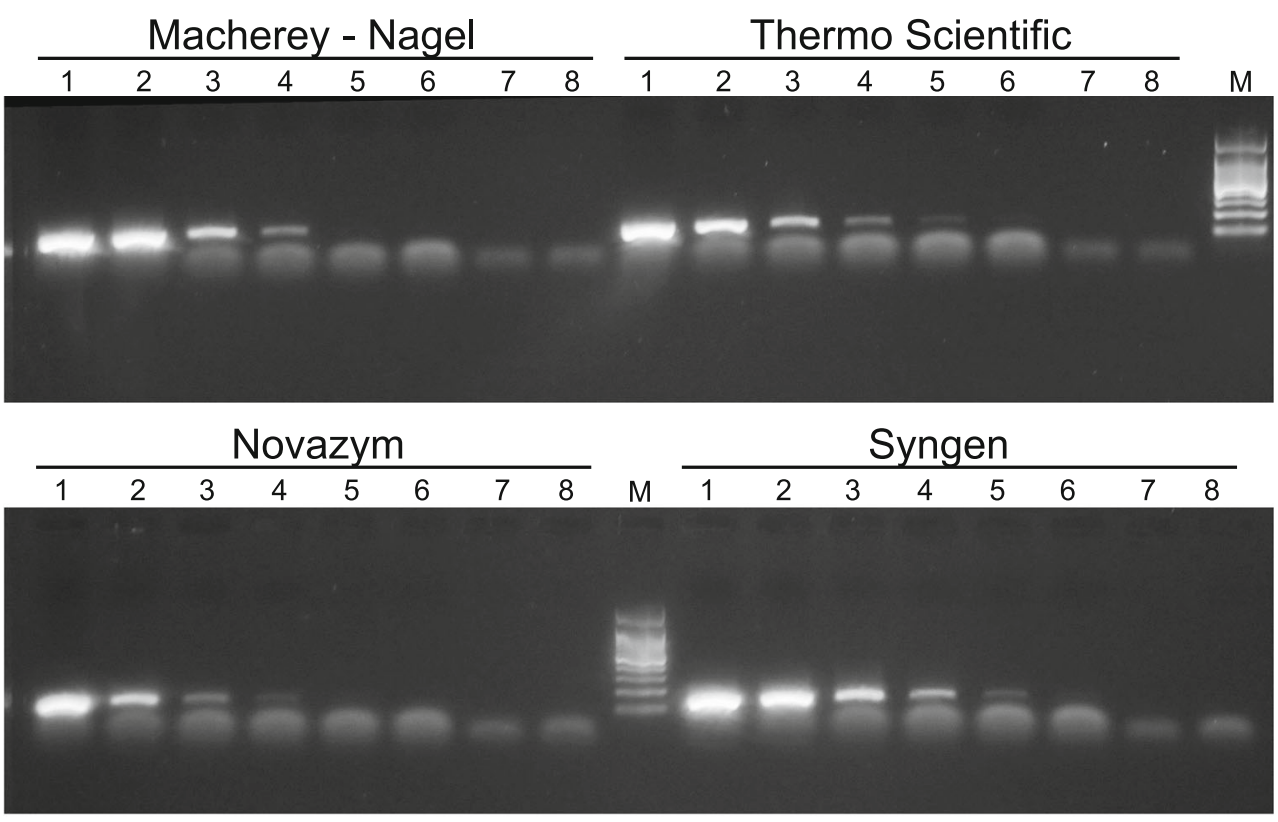

A\&A Biotechnology

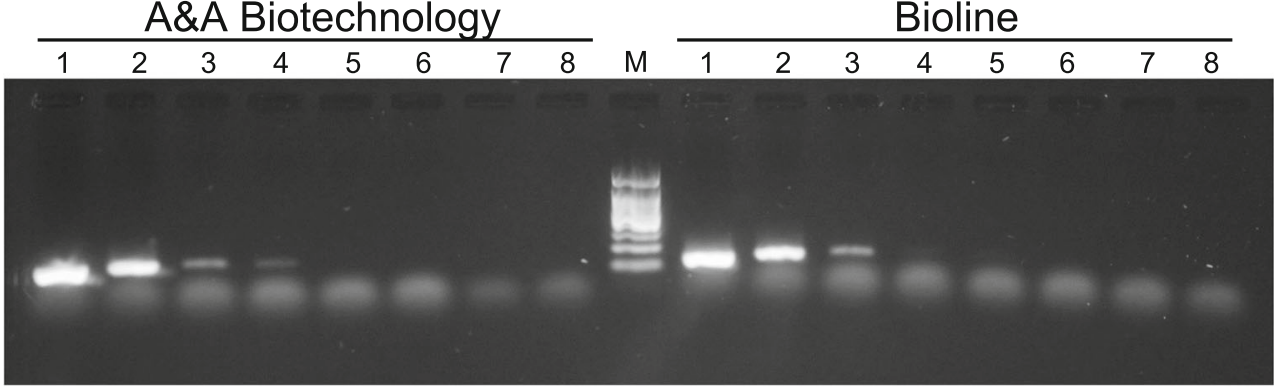

Silica capture

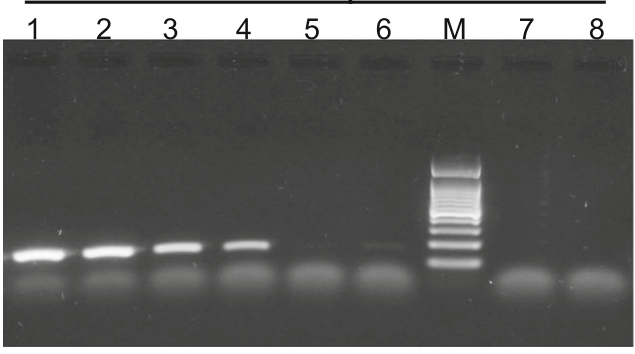

yielded low amount of RNA. Longer isolation (60 min) using kit B was recompensed by very easy procedure and good yield of RNA. Kit E required multistep procedure but resulted in good yield. The lowest RNA yield was obtained with kit F while the most concentrated preparation was purified using kit C (Table 1). However, this kit was the longest and the most difficult to perform among tested methods resembling original manual RNA purification according to Chomczynski and Sacchi (2006). In our assays, the silica capture RNA isolation was almost as cost effective as kit $\mathrm{C}$ and as easy as kits $\mathrm{A}$ and $\mathrm{D}$.

While the silica capture method purifies both RNA and DNA, it was reported that presence of DNA in the sample doesn't interfere with detection of RNA viruses by RT-PCR (Malinowski 1997). Our results confirm this information. RT-
PCR performed on dilutions of total nucleic acid isolated by silica capture method was as sensitive as on the dilutions of RNA prepared by kits B and D, where positive band was detected at lowest tested RNA concentration (Fig. 3). Moreover, silica capture RT-PCR was more sensitive than RT-PCR performed on RNAs isolated by kits A, C, E and F (Fig. 3). Commercial kits can significantly facilitate RNA isolation; however these kits should be carefully tested for detection of sensitivity, length of the procedure and cost efficiency before application in potato certification schemes.

As the guanidinium salt was not suitable for isolation of RNA from plants rich in polysaccharides (Gambino et al. 2008), guanidinium-free protocols have been developed ( $\mathrm{Li}$ et al. 2008; Ghawana et al. 2011; Kumar et al. 2011). Some 
of these protocols included silica or silica columns (Ding et al. 2008; Sangha et al. 2010). However these methods were not verified for potato and are composed of many steps, limiting their application for routine diagnostics. Moreover our results demonstrated that the combination of buffers used in silica capture procedure does not negatively affect PVY detection in potato tissues, even when they are rich in polyphenols (Singh 1998) and have high activity of polyphenol oxidases and peroxidases, making them a particularly difficult source of samples for RT-PCR (Singh and Singh 1996). Singh et al. (2002) developed RNA isolation protocol eliminating inhibitory effect of these compounds on RT-PCR. To prevent oxidative damages they incorporated sodium sulfite at the nucleic acid extraction step and to remove polysaccharides they applied phenol/ chloroform extraction as well as isopropanol precipitation (Singh et al. 2002). Detection of potato viruses, based on their protocol, was more sensitive compared to RNA isolated via RNAeasy kit (Singh et al. 2002). Moreover it was shown to be beneficial for PVY detection by real time RT-PCR (Singh et al. 2012). However, the protocol developed by Singh et al. (2002) is composed of many steps, includes sample digestion with DNAse I and proteinase $\mathrm{K}$ as well as organic solvents for extraction and precipitation steps (Singh et al. 2002). This generates additional costs and creates hazardous organic wastes. Silica capture method adapted here is faster and avoids phenol. Moreover it eliminates RT-PCR inhibitors efficiently and allows for sensitive PVY detection (Fig. 3). Tree tissues also contain high level of phenolic and polysaccharide compounds and are difficult source for RNA isolation. Similarly to results described in this paper for PVY detection in potato tubers, silica capture RT-PCR was successfully used for detection of several viruses of cherry (Rott and Jelkmann 2001). Both for PVY (here) and for cherry viruses (Rott and Jelkmann 2001) the silica capture was as easy to use as commercial kits while being more cost-efficient. Also the silica capture can be farther adapted to high-throughput assays by application of microplate filtration systems or empty centrifugal columns.

Acknowledgments Authors thank Dr. Aurelie Rakotondrafara and Dr. Betty Chung for discussions and the critical reading of the manuscript. This study was financially supported by the Polish Ministry of Agriculture and Rural Development.

Open Access This article is distributed under the terms of the Creative Commons Attribution License which permits any use, distribution, and reproduction in any medium, provided the original author(s) and the source are credited.

\section{References}

Agindotan, B.O., P.J. Shiel, and P.H. Berger. 2007. Simultaneous detection of potato viruses, PLRV, PVA, PVX and PVY from dormant potato tubers by TaqMan real-time RT-PCR. Journal of Virological Methods 142: 1-9.
Barker, H., K.D. Webster, and B. Reavy. 1993. Detection of potato virus $\mathrm{Y}$ in potato tubers: a comparison of polymerase chain reaction and enzyme-linked immunosorbent assay. Potato Research 36: 13-20.

Bolotova, Y.V., A.V. Karasev, and C.S. McIntosh. 2009. Statistical analysis of the laboratory methods used to detect potato virus Y. American Journal of Potato Research 86: 265-271.

Boom, R., C.J. Sol, M.M. Salimans, C.L. Jansen, P.M. Wertheim-van Dillen, and J. van der Noordaa. 1990. Rapid and simple method for purification of nucleic acids. Journal Clinical Microbiology 28: 495-503.

Boonham, N., K. Walsh, R.A. Mumford, and I. Barker. 2000. Use of multiplex real-time PCR (TaqMan) for the detection of potato viruses. EPPO Bulletin 30: 427-430.

Boonham, N., R. Glover, J. Tomlinson, and R. Mumford. 2008. Exploiting generic platform technologies for the detection and identification of plant pathogens. European Journal of Plant Pathology 121: 355-363.

Chomczynski, P., and N. Sacchi. 1987. Single-step method of RNA isolation by acid guanidinium thiocyanate-phenol-chloroform extraction. Analytical Biochemistry 162: 156-159.

Chomczynski, P., and N. Sacchi. 2006. The single-step method of RNA isolation by acid guanidinium thiocyanate-phenol-chloroform extraction: twenty-something years on. Nature Protocols 1: 581-585.

Clark, M.F., and A.N. Adams. 1977. Characteristics of the microplate method of enzyme-linked immunosorbent assay for the detection of plant viruses. Journal of General Virology 34: 475-483.

Crosslin, J.M., and L.L. Hamlin. 2011. Standardized RT-PCR conditions for detection and identification of eleven viruses of potato and potato spindle tuber viroid. American Journal of Potato Research 88: 333-338.

Ding, L.W., Q.Y. Sun, Z.Y. Wang, Y.B. Sun, and Z.F. Xu. 2008. Using silica particles to isolate total RNA from plant tissues recalcitrant to extraction in guanidine thiocyanate. Analytical Biochemistry 374: 426-428.

Du, Z., J. Chen, and C. Hiruki. 2006. Optimization and application of a multiplex RT-PCR system for simultaneous detection of five potato viruses using $18 \mathrm{~S}$ rRNA as an internal control. Plant Disease 90: $185-189$.

Fox, A., F. Evans, and I. Browning. 2005. Direct tuber testing for potato Y potyvirus by real-time RT-PCR and ELISA: reliable options for post-harvest testing? EPPO Bulletin 35: 93-97.

Gambino, G., I. Perrone, and I. Gribaudo. 2008. A rapid and effective method for RNA extraction from different tissues of grapevine and other woody plants. Phytochemical Analysis 19: 520-525.

Ghawana, S., A. Paul, H. Kumar, A. Kumar, H. Singh, P.K. Bhardwaj, A. Rani, R.S. Singh, J. Raizada, K. Singh, and S. Kumar. 2011. An RNA isolation system for plant tissues rich in secondary metabolites. BMC Research Notes 4: 85.

Hill, S.A., and E.A. Jackson. 1984. An investigation of the reliability of ELISA as a practical test for detecting potato leaf roll virus and potato virus $\mathrm{Y}$ in tubers. Plant Pathology 33: 2126.

Knorr, D., S.D. Schoen, and G. Leone. 1996. Detection of potato leafroll virus in dormant potato tubers by immunocapture and a fluorogenic 5' nuclease RT-PCR Assay. Phytopathology 86: 993-999.

Kostiw, M. 2011. The occurrence of major potato viruses in Poland. Journal of Plant Protection Research 51: 204-209.

Kumar, G.R.K., N. Eswaran, and T.S. Johnson. 2011. Isolation of highquality RNA from various tissues of Jatropha curcas for downstream applications. Analytical Biochemistry 413: 63-65.

Li, R., R. Mock, Q. Huang, J. Abad, J. Hartung, and G. Kinard. 2008. A reliable and inexpensive method of nucleic acid extraction for the PCR-based detection of diverse plant pathogens. Journal of Virological Methods 154: 48-55.

Malinowski, T. 1997. Silica capture-reverse transcription-polymerase chain reaction (SC-RT-PCR): application for the detection of several 
plant viruses. Diagnosis and Identification of Plant Pathogens 11: 445-448.

Marko, M.A., R. Chipperfield, and H.C. Birnboim. 1982. A procedure for the large-scale isolation of highly purified plasmid DNA using alkaline extraction and binding to glass powder. Analytical Biochemistry 121: 382-387.

Mortimer-Jones, S.M., M.G.K. Jones, R.A.C. Jones, G. Thomson, and G.I. Dwyer. 2009. A single tube, quantitative real-time RT-PCR assay that detects four potato viruses simultaneously. Journal of Virological Methods 161: 289-296.

Nie, X., and R.P. Singh. 2000. Detection of multiple potato viruses using an oligo(dT) as a common cDNA primer in multiplex RT-PCR. Journal of Virological Methods 86: 179-185.

Nolasco, G., C. De Blas, V. Torres, and F. Ponz. 1993. A method combining immunocapture and PCR amplification in a microtiter plate for the detection of plant viruses and subviral pathogens. Journal of Virological Methods 45: 201-218.

Rott, M.E., and W. Jelkmann. 2001. Characterization and detection of several filamentous viruses of cherry: adaptation of an alternative cloning method (DOP-PCR), and modification of an RNA extraction protocol. European Journal of Plant Pathology 107: 411-420.

Sangha, J.S., K. Gu, J. Kaur, and Z. Yin. 2010. An improved method for RNA isolation and cDNA library construction from immature seeds of Jatropha curcas L. BMC Research Notes 3: 126.

Singh, R.P. 1998. Reverse-transcription polymerase chain reaction for the detection of viruses from plants and aphids. Journal of Virological Methods 74: 125-138.

Singh, R.P. 1999. Development of the molecular methods for potato virus and viroid detection and prevention. Genome 42: 592-604.

Singh, R.P., and X. Nie. 2003. Multiple virus and viroid detection and strain separation via multiplex reverse transcription-polymerase chain reaction. Canadian Journal of Plant Pathology 25: 127-134.
Singh, M., and R.P. Singh. 1996. Factors affecting detection of PVY in dormant tubers by reverse transcription polymerase chain reaction and nucleic acid spot hybridization. Journal of Virological Methods 60: 47-57.

Singh, R.P., X. Nie, M. Singh, R. Coffin, and P. Duplessis. 2002. Sodium sulphite inhibition of potato and cherry polyphenolics in nucleic acid extraction for virus detection by RT-PCR. Journal of Virological Methods 99: 123-131.

Singh, R.P., A.D. Dilworth, M. Singh, and D.L. McLaren. 2004. Evaluation of a simple membrane-based nucleic acid preparation protocol for RT-PCR detection of potato viruses from aphid and plant tissues. Journal of Virological Methods 121: 163-170.

Singh, M., R.P. Singh, M.S. Fageria, X. Nie, R. Coffin, and G. Hawkins. 2012. Optimization of a real-time RT-PCR assay and its comparison with ELISA, conventional RT-PCR and the grow-out test for large scale diagnosis of potato virus $\mathrm{Y}$ in dormant potato tubers. American Journal of Potato Research 90: 43-50.

Spiegel, S., and R.R. Martin. 1993. Improved detection of potato leafroll virus in dormant potato tubers and microtubers by the polymerase chain reaction and ELISA. Annals of Applied Biology 122: 493-500.

Treder, K., W. Przewodowski, and A. Barnyk. 2009. Factors influencing detection of potato leafroll virus and potato virus $\mathrm{Y}$ in potato tuber extracts. Plant Breeding and Seed Science 59: 65-74.

Whitworth, J.L., P. Nolte, C. McIntosh, and R. Davidson. 2006. Effect of potato virus $\mathrm{Y}$ on yield of three potato cultivars grown under different nitrogen levels. Plant Disease 90: 73-76.

Wróbel, S. 2014. Modification of ELISA by replacing incubation of microtiter plates in an incubator with their shaking in PVY, PVM and PLRV detection. American Journal of Potato Research. doi:10. 1007/s12230-013-9355-7.

Wróbel, S., and A. Wasik. 2013. Seed potato production in Poland. American Journal of Potato Research. doi:10.1007/s12230-013-9346-8. 